\title{
PSYCHE
}

VoL. 57

DeCember, 1950

No. 4

\section{THE GENERIC NAMES FOR TABANIDAE (DIPTERA) PROPOSED BY ADOLFO LUTZ ${ }^{1}$}

\author{
By G. B. FAIRCHILD ${ }^{2}$ \\ University of Minnesota
}

Beginning in 1905, Dr. Adolfo Lutz published a considerable number of papers on South American Tabanidae, mainly the Brazilian fauna. He had evidently intended to monograph the fauna, and did treat the Pangoniinae, the Diachlorini and the genera Dichelacera, Stibasoma and Acanthocera in a thorough way. His other publications on the family consisted mostly of local lists, descriptions of new species, and short papers outlining his views on the generic classification of the Neotropical species.

In his papers of a monographic or revisional nature, Dr. Lutz appears to have well understood the rules governing zoological nomenclature, and new names appearing in these publications are for the most part validly proposed. In his papers on general classification and in his local lists, however, which he seems to have considered of a preliminary nature, it appears that he did not realize that the names he was using were then appearing for the first time and would have to be taken into consideration by subsequent students. In many cases these names were so casually proposed, either without adequate definition or without valid included species, and almost always without bibliographic reference, that it has proven very difficult to come to a decision on their validity. In other cases, it has been difficult to decide on the year in which a certain name, published as new on several occasions, was validated.

${ }^{1}$ Paper No. 2455 of the Scientific Journal Series, Minnesota Agricultural Experiment Station, St. Paul 1, Minnesota.

${ }^{2}$ On leave of absence 1949-1950 from Gorgas Memorial Laboratory, Panama, Republic of Panama. 
Several students have attempted to clarify these matters, notably Bequaert (1924) who selected genotypes of many of Lutz' genera and Borgmeier (1933) who, with better access to Lutz' published works, corrected the dates of first appearance of some of his names and added others overlooked by previous workers. Enderlein (1922, 1925) and Kröber (1932, 1934) have used a number of Lutz' names, and placed a good many more in synonymy, in some cases without adequate consideration.

In spite of these efforts, however, no complete listing of Lutz' generic names has appeared, nor has the status of a number of them ever been carefully examined in the light of the International Rules of Zoological Nomenclature. The present paper is an attempt to do this. I have seen, I believe, all of Lutz' publications, except one, which contain new generic names for Tabanidae, though there is always the possibility that others will turn up. Carlos Chagas (1925, 1929, 1934) published a list, with supplements, of Lutz' published works on all subjects numbering over 200 , but even it contains some errors and omissions. His papers dealing, in whole or in part, with Tabanidae number 27 , of which about 17 contain matter of nomenclatorial importance. I have appended a list of all his papers containing references to Tabanidae of which I have knowledge, but there may be others.

Lutz appears to have published, alone or jointly, 43 generic names. Some of these were variants in spelling or new names to replace preoccupied names, but 32 seem to refer definitely to newly defined groups of generic or subgeneric rank. All these names are here listed, together with references to their first appearance in print and remarks on their validity. I have not attempted to show synonymies except in a few undoubted cases, as generic and subgeneric concepts in Tabanidae are still in a rather fluid state.

The most difficult point to settle is the status of the names published in the $1909 \mathrm{c}$ list. This publication is an illustrated brochure or guide book giving a description of the physical plant and investigations being undertaken by the Instituto Oswaldo Cruz. It also contains lists of the collections, publications, and library. It bears no date other than the year, and no authorship. In the list of Tabanidae, 15 new generic names are proposed, being indicated by "nov. gen." or "n. gen." in all cases. 13 of these appear with valid specific names, and, although the International Rules are somewhat loosely worded on this point, I believe, ignoring other considerations, 
they are thereby validated. In regard to the authorship, it is now well known that Lutz was the author of this list. It is doubtful if he realized that the names appearing therein were being published in the nomenclatorial sense as he never subsequently referred to this paper although he consistently used the names proposed therein. $\mathrm{He}$ himself gave me my copy, and the whole list, with minor changes, was republished in $1911 \mathrm{a}$, where the new genera are all credited to Lutz, according to Borgmeier. I have not been able to secure a copy of this paper, but it seems to have been also in the nature of a guidebook to the exhibit of the Instituto Oswaldo Cruz at some sort of international scientific exposition.

The difficulty in accepting these names as of 1909 lies not only in a lack of definitions, (which is of less importance, as the names were published before 1930 , when the rules on this point were modified), but in the dubious character of the publication itself. The pamphlet is anonymous, it is not a periodical, nor any regular form of scientific publication, and there is much probability that it was never intended or offered for sale, though it may have had wide distribution. There is, thus, strong reason for considering that the names appearing in it were not validly published and are hence unavailable as of that date. If this stand be taken, the next chronological appearance of the names must be considered. This was the 1911 a paper, which seems to have suffered from all the faults of its predecessor except anonymity. (The Pangoniinae may be excluded from further consideration, as the new genera of this division were all validly proposed with definitions or species in recognized journals in 1909, so that they date from this year in any case). If the $1911 \mathrm{a}$ paper be excluded from consideration nomenclatorially, the next in chronological order is 1912 , where Dicladocera, although not defined as a genus, is accompanied by the description and figure of a valid species in a nomenclatorially acceptable publication. The difficulty here is that this species, unicolor Lutz, appears not to be congeneric with the species previously included, as Bequaert and Rengifo (1947 Psyche, 53 [3-4]:68) have pointed out, necessitating the use of Enderlein's Dasychela for the species placed by Lutz in Dicladocera.

Lutz' 1913a paper validates Stigmatophthalmus and adds Himantostylus. Then, also in 1913, comes the first exposition of Lutz' scheme for the classification of the Tabaninae. Here appear all the remaining names of the $1909 \mathrm{c}$ list, plus four additional new ones. They are not formally proposed as new genera and are not ac- 
companied by specific names or references to previous publications, but they are recognizably defined by being placed in a key. They appear in an acceptable publication and would seem certainly available nomenclatorially as of this date. This paper was published twice, the first time above, and a year later, 1914b, where it is accompanied in parallel columns by a German translation, a common custom at that time in this journal. I can find no changes whatever in the later edition. Between the appearances of these two "editions", the 1914a paper appeared. In lists of species all the remaining $1909 \mathrm{c}$ names appear and are accompanied by valid specific names except Macrocormus while several of the names first published in 1913 are here accompanied by valid specific names for the first time. Macrocormus does not appear with a valid specific name in an acceptable publication until 1918, where it is listed as " $\boldsymbol{T}$. (Macrocormus) rubescens Bigot" and "Macrocormus sorbillans".

It is thus seen that if the names appearing in the $1909 \mathrm{c}$ and $1911 \mathrm{a}$ papers are not considered nomenclatorially available as of these dates, they became available in 1913 when they were defined, or in 1912,1914 , or 1918 when they were accompanied by valid specific names. This change in dates appears to affect but two of these names, Dicladocera, which changes its sense as mentioned above and Neotabanus which becomes a homonym of Neotabanus Ricardo 1911 (Rec. Ind. Mus. 4:363, Type N. ceylonicus Ric. 1911). No new proposal of name for Neotabanus Lutz is necessary, since Taeniotabanus Kröber 1930 (Dipt. Pat. S. Chile P. 140, Type T. occidentalis Linn.) is already available. In any event the group is hardly of subgeneric rank and may eventually prove undefinable.

The author has hitherto been inclined to take a liberal view of the case and accept the 1909 dating, though for the sake of forestalling possible future controversy, it might be well to adhere to a stricter interpretation of the rules and accept 1913 as the date for these names.

Amphichlorops, Lutz 1909c, p. 29, with $A$. flavus Wied., and $A$. variegatus n. sp. $1913 \mathrm{~b}$, defined in key. 1914a, with flavus Wied., Type T. flavus Wied. 1828 (Bequaert 1924).

Bombylopsis Lutz 1909a, p. 31, with nitens (Bigot), ?analis (Fab.) and leonina n. sp. $1909 \mathrm{~b}$, p. 646, with erythronotata Big., pseudoanalis n. sp., analis Fab. 1805 and leonina n. sp. 1909c, p. 28, with erythronotata Big., ?analis Fab. and leonina n. sp. Type erythronotata Big. (Borgmeier 1933). 
Bombylomorpha Lutz 1911a, p. 33, with erythronotata Big., pseudoanalis n. sp., analis Fab. and leonina n. sp. Type erythronotata Bigot (Borgmeier 1933).

Bombylomyia Lutz 1911 b, p. 69 with B. splendens n. sp. descr. Bombylopsis changed to Bombylomyia. 1914a with nitens Big. The status of these names is confusing. Bombylomorpha and Bombylomyia may have been created to replace Bombylopsis, thought to be preoccupied. I have been unable to find that this name is preoccupied and Lutz and Castro 1936 have reverted to its use. The selection of erythronotata Big. as type of Bombylopsis is incorrect, as it was not included in the original publication. The only species available as genotype for Bombylopsis is nitens Bigot 1892 and it is here selected. Since both Bombylomyia and Bombylomorpha were substitute names, they take the same genotype. Ionopis or Ionopsis (q.v.) will fall as a synonym, as it has the same genotype. There is no need to replace the latter name until it becomes clear that the concept it was intended to cover is needed.

Catachlorops 1911a. emendation of Katachlorops (q.v.).

Chelotabanus 1913b, p. 5, in key, no species. 1914a, p. 72, with fuscus Wied., impressus Wied., aurora Macq., cinerarius Wied. 1918 with aurora and impressus. See Odontotabanus. Type $I$. fuscus Wied. 1819 (Bequaert 1924).

Chlorotabanus $1909 \mathrm{c}$, p. 30, with mexicanus L. $1913 \mathrm{~b}$, in key, no species. 1914a, with mexicanus L. $1911 \mathrm{a}$, with mexicanus L. Type T. mexicanus L. 1767 (Bequaert 1924).

Chrysochiton Lutz and Castro, 1936, with auricinctus (Lutz and Neiva) bocainensis n. sp., nubiapex (Lutz) and rubrithorax (Kröb.). Type by original designation, Erephopsis auricinctus Lutz and Neiva 1909.

Cryptotylus 1909c, with unicolor Wied. 1911a with unicolor Wied. 1913b defined in key (Chryptotylus). Monotypic for T. unicolor Wied. 1828 (Borgmeier 1933).

Dicladocera 1909c, p. 29, with immaculata Macq., furcata Wied. (macrodonta Macq.), potator Wied., guttipennis Wied., macula (scutellata) Macq., luctuosa Macq, and rufipennis Macq. 1911a, p. 34, with same species. 1912, with $D$. unicolor Lutz n. sp. descr. $1913 \mathrm{~b}$, defined in key (Dichladocera.) Type T. guttipennis Wied, 1828 (Enderlein 1922). The designation of unicolor Lutz by Bequaert (1924) and his subsequent restriction 
(1946 p. 68) rest on the assumption that Lutz' 1909c names were invalidly published. See introductory discussion above.

Dyspangonia 1905, p. 22. defined and with fuscipennis Wied., clari

n. sp., fasciata Macq., lugubris Macq., ferruginea Macq. 1909b

p. 625=Esenbeckia Rond. Type Pangonia fuscipennis Wied. 1828 (Bequaert 1924).

Epipsila 1909b, p. 648 with eriomera Macq. and eriomeroides n. sp. descr. Type E. eriomeroides Lutz (Enderlein 1925).

Himantostylus 1913a, p. 183, defined and with intermedius n. sp. descr. Monotypic (not Himanthostylus Borgm. 1933).

Ionopsis $1909 \mathrm{c}$, p. 28 with nitens n. gen. (sic) and Foetterlei n. sp. 1909 b, p. 650 defined and with nitens Bigot and Foetterlei n. sp. described (Ionopis). The spelling will depend on which of these publications appeared first. Neave's Nomenclator gives Ionopis, while Borgmeier (1933) maintains that Ionopsis was the original spelling. Type nitens Bigot 1892 (Enderlein 1925). The type species was originally included in Bombylopsis Lutz 1909a (q.v.) which has some months priority.

Katachlorops 1909 c, p. 29, with fuscipennis Macq., rufesceus Fab. intereuns Walk., capreolus Wied. and bitinctus Walk. 1911a, p. 34. with same species. $1913 \mathrm{~b}$, defined in key only (Cathachlorops, Gatachlorops) Type. Dichelacera fuscipennis Macq. 1847 (Bequaert 1924). The emended spelling Catachlorops, has largely prevailed.

Laphriomyia 1911 b, p. 70. defined and with mirabilis n. sp. descr. The erroneous variant Laphriopsis appears on p. 71. 1911a p. 34 (Laphromyia) Monotypic for L. mirabilis Lutz 1911.

Leptotabanus 1914a, p. 72, with nigrovenosus Lutz in list of Tabanidae from Xerem. 1918, in list only, no authority. 1921, in list only, no authority. The species seems never to have been described, though it is possible that Melanotabanus fuliginosus Lutz and Neiva (q.v.) was based on the same specimen. It is described in the same paper from a single specimen from $\mathrm{Xerem}, \mathrm{Rio}$ de $\mathrm{Janeiro,}$ and the authors state in the paragraph preceding their list of Tabanidae from Xerem that the list includes a new species based on one specimen from Xerem. Leptotabanus nigrovenosus is the only new species in this list. Since the name is invalid, a nomen nudum, as listed by Neave, it does not preoccupy Leptotabanus Kröber 1931 as believed 
by Miller (1945), who proposed the unnecessary name Neoleptotabanus (Proc. Roy. Ent. Soc. London (B) 14:72).

Leucotabanus $1913 \mathrm{~b}$, defined in key. 1914a, p. 71, with leucaspis Wied. in list. 1914b, defined in key. Type Tabanus leucaspis Wied. 1828 (Bequaert 1924)).

Macrocormus 1909c, p. 29, with badius n. sp. sorbillans Wied., pseudosorbillans n. sp. and trizonophthalmus n. sp., 1911a, p. 35 with same species. $1913 \mathrm{~b}$, defined in key. Type Tabanus sorbillans Wied., 1928 (Bequaert 1924).

Melanotabanus 1914a, p. 76. defined and with fuliginosus n. sp. described. Monotypic.

Micropangonia 1922, p. 5, defined briefly by comparison with Erephopsis. Said to contain two species, but none named. I believe this to be a lapsus for Neopangonia Lutz (q.v.) as the characters mentioned (open first posterior cell, long proboscis and small size) are those used earlier to separate Neopangonia from "Erephopsis". Since the name could be construed as having been defined, and hence valid, I hereby select $\mathrm{Neo-}$ pangonia pusilla Lutz 1909 as genotype, as it agrees with the definitions, thus making Micropangonia a synonym of $\mathrm{Neo-}$ pangonia.

Microtabanus 1922, p. 9, defined only by having unicolorous eyes and being small. No species. This can hardly be construed as a "definition" under the rules, and I consider the name invalid and not preoccupying Microtabanus Fairchild 1937.

Myiotabanus 1928, p. 59, with sarcophagoides n. sp. descr. and fig. Although there is no statement that the genus is proposed as new, it is combined with a valid specific name and I believe should be considered valid. Monotypic.

Neopangonia 1909b, p. 651, defined and with pusilla n. sp. descr. and fig. Monotypic. See also Micropangonia.

Neotabanus 1909c, p. 29, with trilineatus Latr., modestus Wied. and 16 other named species. 1911a, with same species. 1913b, defined in key. 1914ia, with obsoletus Wied., comitans Wied., ixyostactes Wied., ochrophilus Lutz, triangulum Wied., trilineatus Latr. and others in list. Type Tabanus trilineatus Latr. 1814 (Bequaert 1924).

Odontotabanus $1918 \mathrm{Lutz}$, Araujo and Fonseca, with aurora, cinerarius, fuscus. 1926 Bequaert, Exped. Amazon, p. 233, cited 
in synonymy with aurora. Lutz 1928, p. 56-57, with cinerarius Wied., testaceus Macq., olivaceiventris Macq., and importunus Wied. in list. Type aurora Macq. 1838 (Borgmeier 1933). Doubtfully distinct from Chelotabanus; Lutz used both names interchangeably in 1918.

Orthostylus 1914a, p. 74, defined and with ambiguus n. sp. descr. Monotypic. Preoccupied. See below.

Orthostyloceras Lutz in Borgmeier 1933, p. 298. New name for Orthostylus Lutz and Neiva, not Orthostylus Beck 1837 Mollusca. Type ambiguus Lutz and Neiva 1914.

Phaeoneura 1909a, p. 645, defined in key and with basilaris Wied. sole species. 1909c, p. 29, with basilaris Wied. in list. $1911 \mathrm{~b}$, with basilaris in list (in German translation the name is Phaeomyia, evidently a lapsus).

Phaeotabanus 1913b, defined in key. 1914a, in list with litigiosus Walk., aphanipterus Wied. Type Tabanus litigiosus Walk. 1850 (Bequaert 1924).

Poecilosoma 1909c, in list with punctipenne Macq., quadripunctatum Macq., histrio Wied., and cinereum Wied. 1911a, same species. 1913b, defined in key. Type Tabanus quadripunctatus Fab. 1805 (Bequaert 1924). (The name is four times preoccupied).

Poeciloderas 1921, in list with "quadripunctatum". Type T. quadripunctatus Fab. 1805 (Borgmeier 1933).

Poecilochlamys 1922, briefly defined and in key. 1928, in list with quadripunctatus Fab. Type T. quadripunctatus Fab. (Borgmeier 1933). The key is the same as the $1913 \mathrm{key}$, and this name replaces Poecilosoma in it.

Pseudocanthocera 1913b, in key, no species. 1914a, in list with marginata Macq., Silveirii Macq. Type Silvius Sylveirii Macq. 1838 (Enderlein 1925).

Plesiophthalmus 1911a (not seen), with fenestratus Lutz undescribed. Monotypic. Nomen nudum. Preoccupied by Motschoulsky 1858 Coleopt. (Borgmeier 1933).

Pseudoscione 1918, in list as Pseudoscione longipennis Ricardo. No description. 1928, p. 54, proposed for Diatomineura longipennis Ricardo and an unnamed species from Ecuador. Species said to resemble Scione but have venation like Diatomineura. No statement that genus is proposed as new. Genotype Diatomineura longipennis Ricardo 1902 here designated. 
Rhabdotylus 1909c, p. 29, with viridiventris Macq. and planiventris Wied. $1913 \mathrm{~b}$, defined in key. 1914a, with viridiventris Macq. in list. Type T. planiventris Wied. 1828 (Bequaert 1924).

Stenotabanus $1913 \mathrm{~b}$, defined in key. 1914a, with taeniotes Wied. in list. Type T. taeniotes Wied. 1828 (Bequaert. 1924).

Stictotabanus 1914, in list with anonymous n. sp. and maculipennis Macq. 1918 in list with conspicuus n. sp., no description. 1922, defined as having unicolorous eyes and a spot on the transverse veins; no species. Borgmeier 1933 gives type as $T$. maculipennis Macq. 1834, but this is unjustified, as there are two Macquart species of this name and Lutz did not specify. See also Bequaert 1924, Enderlein 1925. Maculipennis Macq. is invalid. (nec Wied. 1828). The name is very doubtfully valid.

Stigmatophthalmus 1909c, with altivagus n. sp. in list. 1911a. (not seen). 1913a, with altivagus n. sp. descr. and fig. Monotypic.

\section{BIBLIOGRAPHY}

Bequaert, J.

1924. Notes upon Surcouf's treatment of the Tabanidae in the Genera Insectorum and upon Enderlein's proposed new classification of this family. Psyche 31 (1):24-40.

Borgmeier, $T$.

1933. A proposito da nomenclatura dos Tabanidae da regiao neotropica. Rev. Ent. 3 (3) :286-303.

Bequaert, J. AND RENGIFo, S. 1946. The Tabanidae of Colombia. Psyche, 53 (3-4):52-88.

Chagas, C.

1925. Bibliography of Lutz. Mem. Inst. Osw. Cruz. 18(1) :VII-XXII Supplements were issued in 1929 and 1934 but do not appear to have been published in the Memorias.

ENDERLEIN, G.

1922. Ein neues Tabanidensystem. Mitt. Zool. Mus. Berlin, 10(2) :333351.

1925. Studien an blutsäugenden Insekten. 1. Grundlagen eines neuen Systems der Tabaniden. Mitt. Zool. Mus. Berlin 11(2) :1-409.

KROBER, O.

1932. Bermerkungen über die Systematik der neotropischen Tabaniden, Bestimmungstabelle der Subfamilien und Gattungen. Rev. Ent. 2(2):185-202.

1934. Catalogo dos Tabanidae da America do sul e Central incluindo o Mexico e as Antilhas. Rev. Ent. 4(2-3):222-276 and 291-333.

LUTz, A.

1905. Beitraege zur Kenntniss der brasilianischen Tabaniden. Rev. Soc. Sci. Sao Paulo, No. 1, pp. 19-32. June. 
LUTZ, A.

1906. Beiträge zur Kenntnis der brasilianischen Tabaniden. Zweite Mittheilung. Rev. Soc. Sci. Sao Paulo, No. 3-4, pp. 1-4 (Separatabdruck).

LUTz, A.

1907. Bemerkungen über die Nomenclatur und Bestimmung der Brasilianischen Tabaniden. Zentralblatt f. Bakteriologie, Abt. 1, Vol. 44, pp. 137-144. Some specific synonymies, no new names.

LuTz, A. AND Nerva, A.

1909. Erephopsis auricincta, uma nova motuca da subfamilia Pangoninae. Mem. Inst. Osw. Cruz, 1 (1) :12-13, Pl.1.

Lutz, A. AND NeIva, A.

1909.a Contribuiçoes para o conhecimento da fauna indijena de Tabanidas. Mem. Inst. Osw. Cruz, 1 (1) : 28-32. April. (in Portuguese and German).

LUTz, A.

1909b Tabaniden Brasiliens und einiger Nachbarstaaten. Zool. Jahrb., Suppl. X, heft 4, pp. 619-692, pl. 1-3, August.

LUTz, A.

1909c Instituto Oswaldo Cruz en Manguinhos, Rio de Janeiro, Colleccao de Tabanidas, pp. 28-30.

LUTz, A.

1910. Notas dipterologicas. Mem. Inst. Osw. Cruz, 2:58-59.

LUTz, A.

1911a (list of Tabanidae) in "Internationale Hygiene-Ausstellung, Dresden 1911, Institut Oswaldo Cruz, Manguinhos, Rio de Janeiro, Brasil", pp. 33-35. (Not seen. According to Borgmeier this is a reprinting of the $1909 \mathrm{c}$ brochure, with some changes, in which the new generic names are credited to Lutz).

1911b Novas contribuiçoes para o conhecimento das Pangoninas e Chrysopinas do Brazil. Mem. Inst. Osw. Cruz, 3 (1) :65-85, Pl. 4.

LUTz, A.

1912. Commissao de Linhas Telegraphicas Estrategicas de Matto Grosso ao Amazonas. Annexo 5, Historia Natural, Zoologia. Tabanideos. pp. 1-9, 1 plate.

LUTz, A.

1912a Contribuiçao para o estudo da biologia dos dipteros hematofagos. III Sangue verde em Tabanidas e outros dipteros. Mem. Inst. Osw. Cruz. 4 (1) :79-81.

LUTz, A.

1913a Tabanidas do Brazil e de alguns Estados visinhos. Mem. Inst. Osw. Cruz. 5 (2) :142-191, pl. 12-13.

1913.b Sobre a systematica dos tabanideos, subfamilia tabaninae. Brazil Medico, No. 45, 1 December 1913. (reprint pp. 1-7).

LUTz, A.

1914. Notas Dipterologicas. Contribuiçao para o conhecimento dos primeros estados de tabanideos brasileiros. Mem. Inst. Osw. Cruz, 6 (1) 43-49. 
LUtz, A. ANd NeIva, A.

1914a As "Tabanidae" do Estado do Rio de Janeiro. Mem. Inst. Osw. Cruz, 6 (2) :69-80.

LUTz, A.

1914b Sobre a sistematica dos tabanideos, sub-familia tabaninae. Mem. Inst. Osw. Cruz, 6 (3) :163-168.

LUTz, A. and Machado, A.

1915. Viagem pelo rio S. Francisco e por alguns dos seus afluentes entre Pirapora e Joazeiro. Mem. Inst. Osw. Cruz. 7 (1) :5-50, (List of Tabanidae pp. 46-47).

LUTz, A.

1915a Tabanidas do Brazil e de alguns Estados visinhos. Segunda Memoria, Mem. Inst. Osw. Cruz. 7 (1) :51-119, Pl. 19-21.

Lutz, A., Araujo, H. C. de Souza, and Fonseca, Filho, O. da.

1918. Viagem scientifica no rio paraná e a Assuncion, com volta par Buenos Aires, Montevideo e Rio de Janeiro. Mem. Inst. Osw. Cruz, $10: 104-199$.

LUTz, A.

1921. Motucas de Guaratuba. Boletim do Inst. Osw. Cruz, Supplemento dos Memorias, 1 p. 15.

LuTz, A.

1922. Zoologia Medica. Tabanidae ou Motucas. Publicaçao Separada da Folha Medica, Rio de Janeiro, pp. 1-17.

Lutz A. (AND Nunez TOVaR)

1928. Estudios de Zoologia y Parasitologia Venezolanas. Rio de Janeiro, December. (pp. 51-64 and Pl. 8-9 deal with Tabanidae and are to be credited to both authors).

LUTz, A.

1931. Sur Tabanus importunus. Comptes Rend. Soc. Biol. Rio de Janeiro, 109:751.

Lutz, A. And Castro, G. M. DE O.

1935. Sobre algumas novas especies de motucas do genero Esenbeckia Rondani. Mem. Inst. Osw. Cruz 30 (3) :543-562.

Lutz, A. and Castro, G. M. de O.

1936. Consideracoes sobre especies affines do genera Melpia Walker (1850) e descripçao de um genero novo e duas especies novas. Sobre duas especies novas do genero Fidena Walker. Mem. Inst. Osw. Cruz. 31(1):169-183.

Lutz, A. and Castro, G. M. de O.

1937. Sobre uma especie nova do genero Laphriomyia Lutz, e descripçao do macho de $L$. mirabilis Lutz. Mem. Inst. Osw. Cruz. 32 (2) :231-233. 

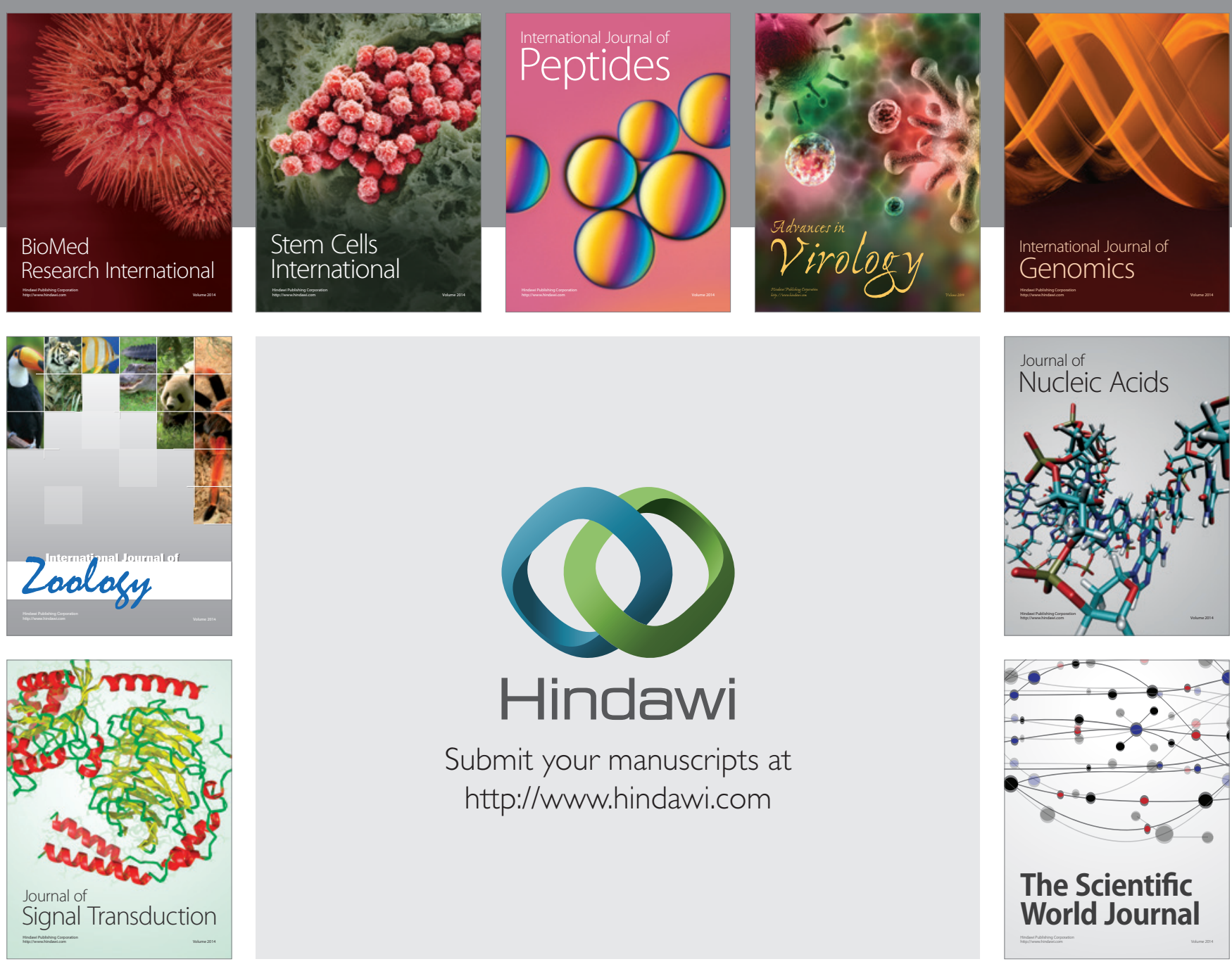

Submit your manuscripts at

http://www.hindawi.com


The Scientific World Journal
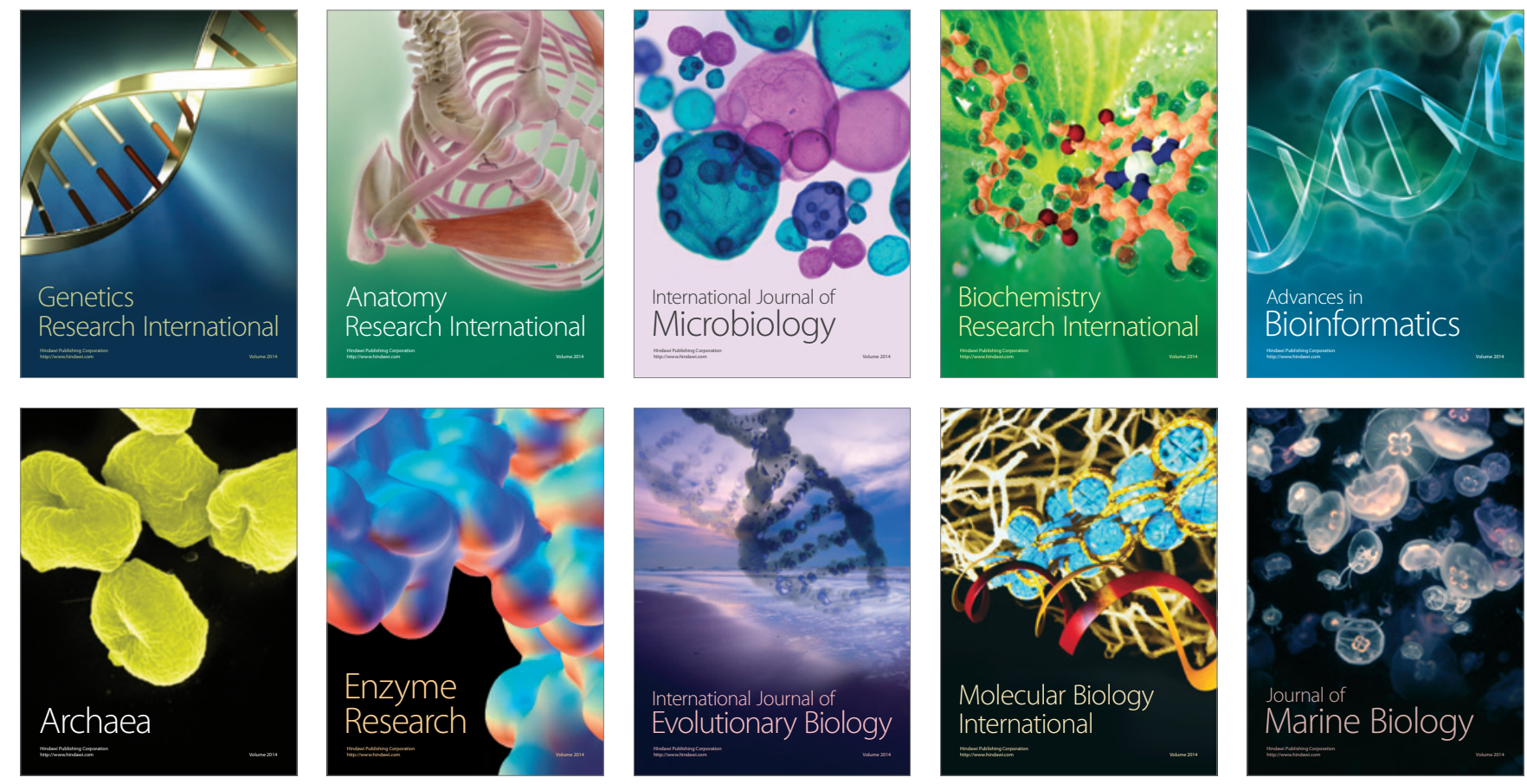